\title{
The Emergence and Evolution of Urban Maori Authorities: A Response to Maori Urbanisation
}

\begin{abstract}
Introduction
When considering cultures and peoples in virtually any context, there can be an underlying tendency to compartmentalise these groups and make assumptions about their features and characteristics that are not necessarily borne out in practice. Nowhere is this more apparent than in the analysis of the dichotomy of traditional and modern societies presented in the writings of the American economists Walt Rostow and Neil Smelser. Rostow and Smelser both cast traditional, non-European communities as having rigid hierarchical systems, limited opportunities for social mobility, fixed limits on productive capacity, low formal educational attainment, and a generally static state of development. ${ }^{1} \mathrm{~A}$ challenge to this depreciatory portrayal was made by the Latin American economist Andre Gunder Frank, who methodically dismantled these stifling classifications of traditional societies. Frank pointed out that constructs used by Rostow and Smelser were essentially a European-imposed perception of how traditional communities operated, and ignored the substantial capacity of these commuities for development - a capacity that would only materialise if such communities were given sufficient self-determination. ${ }^{2}$

The debate about the perception, nature, and capacity of so-called traditional societies in the modern world has a direct bearing on the expectations and understandings of urban

Pare Keiha is Dean of Te Ara Poutama, AUT University's Faculty of Maori Development, Vice Chancellor for Commercialisation, and Pro Vice Chancellor for Maori Advancement. Paul Moon is Professor of History at Te Ara Poutama.
\end{abstract}


Maori in Aotearoa/New Zealand. This chapter explores several themes arising out of an examination of some of the social and structural aspects of Maori urbanisation. These lead to the conclusion that the emergence of Maori urban authorities are now a permanent feature in Maori society, and are an entirely legitimate form of association, in both a structural and cultural sense.

\section{The Capacity for Adjustment - A Brief Historical Survey}

Urbanisation obviously involves communities making substantial adjustments - both in their internal structures and organisation, and in the way they interact externally. Indeed, it could be argued that the extent of the success of a community rests with its ability to effectively undergo such alterations. In the case of Maori society, the facility to accommodate major social and economic transformations has been an enduring feature for at least a thousand years. A brief survey of some of the salient feature of Maori history clearly demonstrates this to be the case.

According to tradition, Aotearoa/New Zealand was first settled by the Polynesian forebears of modern Maori in about AD 800.3 They themselves were in turn the products of a canoe-borne expansion that finds its roots in the islands of South-East Asia reaching back some four to six thousand years. ${ }^{4}$ Maori thus share a common Austronesian ancestry with many nations of both Melanesia and Polynesia. ${ }^{5}$

This preparedness to uproot a community from one location and replant it somewhere elsewhere that is largely unknown to that community can be seen as one of its defining characteristics. Taking a broader historical perspective, the migration of the Polynesians, culminating in the arrival of Maori to New Zealand, could be seen in the context of urbanisation in that it shares many of the same motivators and challenges. It was part of the inexorable spread of civilization across the face of the earth, with peoples leaving their then present positions in the belief that their future 
could be improved by being elsewhere. That urge for improvement is a common feature of peoples driven by two related motivating forces: hope and opportunity. No matter what scale of this phenomenon is being considered, this dynamic - involving the will to improve - remains at its centre. However, the quest for improvement through relocation did not cease when Maori communities began to establish themselves in New Zealand.

The early history of Aotearoa/New Zealand is characterised by both immigration and migration. ${ }^{6}$ Maori history is one characterised by restlessness and the search for opportunity. Clearly, that restlessness, whether it be a function of interNicene warfare or simple curiosity, was sufficient to overcome the bonds of kinship, identity and indeed duty, which might otherwise have prevented such exploration.

One of the biggest challenges that Maori society as a whole embraced took place from the late eighteenth century, with the encroachment of a new and radically different culture in Aotearoa. As a consequence of the visit by the Englishman Captain James Cook in 1769, and the subsequent interest by some British in the growing economic opportunities to be found in New Zealand, the country was progressively settled by non-Maori from the early $1800 s .{ }^{7}$ Eager to trade with Europe, and to acquire the benefits of a modern economy, Maori welcomed this interest. 8 A number of Northland Maori, educated by Anglican missionaries, were encouraged by James Busby, the first British Resident, ${ }^{9}$ to appropriate the political technologies of a then modern state. This culminated, in a political sense, when thirty-five chiefs, mainly from Northland declared New Zealand a free and independent state by the signing of the Declaration of Independence in October of 1835.10 Up to this time, New Zealand was largely a collection of independent tribal nations, with no single sovereign authority presiding over them. All tribes were largely autonomous and held together by political and strategic alliances that were often were fragile at best and fractious at worst. The Declaration was Busby's attempt to establish an international identity for Maori. Whilst declaring Maori independence, the Declaration, amongst other things, 
established a Congress that reserved the right by Maori to create laws and to govern their own affairs, and requested the protection of England over this new state. In return for this assistance, non-Maori would be permitted to live in peace in the country. Significantly it was a document in which Maori reserved and affirmed their sovereignty and independence. ${ }^{11}$

With a growing and unregulated settler population in New Zealand, William Hobson was subsequently sent to New Zealand to establish a Treaty with Maori. ${ }^{12}$ First signed on 6 February 1840 at Waitangi, the Treaty of Waitangi gave foundation to a society of British invention. Rather than being the foundation for the establishment of a just and civil society for all that the British Colonial Office had earnestly intended,13 the Treaty was to become the instrument by which the British eventually acquired sovereignty over Maori.

By the 1850s, the two populations had drawn together numerically, and by the turn of the century, as a result of immigration, wars, and epidemics the non-Maori population outnumbered the Maori population of 40,000 by around 20 to 1.14 The dramatic increase in settler numbers was a trend that was to inevitably drive a demand for land for settlement.15 While Maori vigorously attempted to retain their lands through political and military means, the majority of Maori land had passed to settler ownership by the end of the century. ${ }^{16}$ Today Maori hold barely 3 million of the 66 million acres of land in New Zealand. Consequently, without a strong economy, and without the skills, capital, and capacity to build on, Maori society was reduced to one reliant upon a settler economy and un-sympathetic policies of successive settler governments. ${ }^{17}$

Increasingly Maori are seeking to determine for themselves their own rangatiratanga - particularly that defined through economic development. Maori economic development has been defined as not only the expansion in the output of goods and services, but also an increase in capacity to achieve expansion of output, plus ownership of the means of production (resources, capital, labour) and increase in the ability to exercise management control over production (ownership and control of firms in a market economy) ${ }^{18}-$ emphasis added. Many of the discussions associated with Maori economic development have focussed largely on end- 
state distributive justice arguments rather than the more appropriate process-state theories. ${ }^{19}$ Development, as a process, cannot be achieved by the singular application of end-state theories of distributive justice. ${ }^{20}$ Rather, it is the equality of opportunity that process theories of distributive justice rightly focus on which leads to development. It is important to recognise that equality of opportunity does not necessarily result in equality of distribution, because individuals and communities will choose to use their opportunities according to their own needs or cultural practice. Thus, depending on how those opportunities are utilized, and the vagaries of chance, unequal income and wealth may emerge. In the long run, it is the participation in the process of development that will eventually lead to the creation of competencies that are appropriate for the long-term economic well-being of a particular community. Importantly, this development will be one defined and managed by the particular developing group or community. ${ }^{21}$

\section{Urbanisation in the Maori Context}

In the first half of the twentieth century, unable to support themselves on their remaining lands and driven by the lure of stronger economies in the towns and cities, many Maori tentatively began to migrate to the urban centres. ${ }^{22}$ In the decades following the Second World War, the urban migration of Maori was to mirror the earlier efforts of their Austronesian ancestors. Ironically, their fate was to be no more secure. Where the efforts of colonising governments and war had failed, urbanisation, driven by economic necessity, has perhaps been the most effective instrument by which Maori society, its communities, its language, and its identity has found the most threat. It is also one that has provided the greatest challenge for Maori and New Zealand society as a whole.

The drift of people from traditional, rural-based communities to cities is an experience familiar to many if not most of the world's nations at one time or another, and has 
tended to follow periods of rapid industrialisation. Urbanisation is used, in this context, to describe both the process and result of this type of migration to the cities.

In the 1960s, Smelser catalogued the principal features of the urbanisation of traditional peoples, which he believed had universal application. These included the segregation of economic activities from the traditional setting, the need for a redefinition of economic security, the need for a new division of labour, the emergence of social unrest, the acceptance of new social and moral norms, and the underlying sense of a break from the past.23 It is not difficult to see these patterns having been replicated in New Zealand for Maori in the post-Second World War period.

One of the biggest changes to impact on traditional Maori communities as a product of the urbanisation process is the weakened sense of these communities as spatial entities. ${ }^{24}$ As a corollary to this, the relevance of kinship links, the traditional division of labour, community cohesion, cooperative economic development, and traditional political structures has altered,25 and in most cases, diminished. This does not in any way reduce the 'Maoriness' of these communities, but is simply part of a tradition of social and economic realignment brought about by changes in circumstances that extend back for centuries.

This is not to underestimate the magnitude of the challenges though. The current urbanisation of Maori, which has been in progress for half a century, is unlike any previous experience of relocation for Maori communities. The presentday urban environment in New Zealand has broken the demarcation between the received notions of 'urban' and 'rural'. Indeed, it would be fair to say that some Maori communities could remain on their traditional land and still be subject to almost as many of the same forces of urbanisation as those who actually relocate to the cities.

The reason for this is that the modern industrial-technical city in this country (as in most others in the developed world) actually envelopes the countryside as well. Thus, the differences between Maori in their traditional rural locations and those in cities has become progressively undermined and continues to be so. The urban world is ostensibly a 'created' 
environment as an integral feature of capitalist activity, 26 and it follows that wherever this capitalist activity extends to (and to whatever extent), then so too do the basic features of urbanised life.

The challenges for Maori in the urbanisation process are accentuated by other features as well. Maori, as with many other indigenous peoples in a modern context, have had to struggle to adapt to in a society in which they are increasingly a minority. Moreover, the structural and social changes imposed by modern urbanization, and their effects on traditional frameworks, are unprecedented:

The processes involved in the disintegration of...traditional practices are complex and variable. But there can be no doubt that the characteristic forms of day-to-day life fostered by the expansion of modern urbanism are very different from those in preceding types of society. Here it seems useful to...[speak] of the emergence of a distinct form of 'everyday life' which has a strongly routinised character, stripped of moral meaning and...the 'poetry of life'. Most of what we do in the course of our day-to-day lives, in modern societies, is strictly functional in nature. ${ }^{27}$

In response to the monumental struggle the traditional forms of collective identity associated with the tribe have experienced, Maori have been extremely proactive in finding alternative expressions of social, cultural and, economic organisation - a trait that has centuries of precedent in Maori society.

\section{The Maori Response to development: The Urban Maori Authority}

Contemporarily referred to as the Urban Maori Authority, the most visible Maori response to urbanisation is an association that on the one hand challenges existing Tribal structures, while on the other hand mirrors those practices of the past which rendered null any community institution that 
failed to provide an adequate vehicle for the expression of a common identity usually arising from a common purpose.

In order to apply a sense of scale to this development, it is first useful to consider some of the statistics relating to the Maori population. According to 1996 census data, the Maori ethnic group population numbered 523,374, or 15.1 percent of the New Zealand population. This was a $20.4 \%$ increase from the previous census in 1991 , when 434,847 people, or 13.0 percent of the New Zealand resident population, identified with the Maori ethnic group. This number included both those who belonged to the Maori ethnic group only, and those who belonged to Maori and one or more ethnic groups.

Although the concept of ethnicity is culturally rather than biologically based, in total 579,714 people or 17.3 percent of the population, said they were of Maori descent compared to 511,278 in 1991. Maori descendants who also said they belonged to the Maori ethnic group were far more likely to know their iwi (tribe) (84.8 percent) than Maori who reported Maori descent but not ethnicity (44.7 percent). The 1996 Census recorded that 83 percent of Maori lived in urban areas. The Maori population is relatively young in comparison to the total population. The 1996 median age of Maori was 21.6 years compared to the total population median age of 33.0 years. Children (under 15) made up 37 percent of the total Maori population, compared to only 22.8 percent of the total. Half of the Maori population is expected to be older than 31.7 years in 2051 compared to 21.6 years in 1996 . By comparison, half of all New Zealanders will be over 45 years in 2051, compared to 33 yeas in 1996.28

Over the next five decades, an increasing number of Maori in the present population will reach retirement age. The means that a larger proportion of the Maori population will be in the 65-and-over age group. By 2051, it has been predicted that people aged 65 and over are projected to make up about 13 per cent $(129,000)$ of the total Maori population, compared to only 3 percent $(16,000)$ in 1996 .

The number of Maori children is projected to increase by 27 percent from 202,000 in 1996 to 256,000 in 2051. This means that 1 in 3 New Zealand children in 2051 will be Maori, up from 1 in 4 in 1996. 
In the main working group of 15-64, numbers of Maori are predicted to rise from 329,000 to 608,000 by 2051 , and increase of 85 percent. In is projected that the percentage of New Zealanders who identify as Maori will rise from 15 percent in 2000 to 18 percent by 2025. By 2051, it is projected that Maori could make up 22 percent of the total New Zealand population. ${ }^{29}$

Considered in their totality, these statistics reveal a staggering growth of Maori, not only in real terms, but also as a proportion of the country's population as a whole. Bearing in mind that most of this growth in the Maori population is taking place in an urbanised setting, some of the recent developments within urban Maori communities become more explicable. It is possible, for example, to draw links between expressions of exasperation in preceding decades with more current initiatives aimed at addressing some of the challenges emerging from Maori urbanisation.

As with most changes in society characterised by poverty and fuelled by disaffection, the disruptive nature of Maori urbanisation manifested one part of itself in protest. The 1970s proved to be a turning point for Maori claims for sovereignty and a resurgence of Maori identity. With its origins located in the century-old drive for Maori land rights, and its organisation provided by a new generation of university-educated urban Maori, the popular notion of New Zealand as a racially harmonious and mono-culturally benevolent society was challenged for the first time, and demonstrated to be misplaced. Among the challenges to the predominantly European perception of race relations in New Zealand were the 1975 Maori Land March, and a subsequent number of high profile land occupations. Highlighting breaches of the Treaty of Waitangi and seeking redress for past injustices, the Maori challenge to European colonisation through a largely peaceful Maori protest movement found fertile ground. If anything, it provided a common rallying point for both urban and tribal Maori. It also raised in a modern context the long-standing grievances of a people that had largely been subsumed by the progress of nationhood. For the first time, non-Maori New Zealanders were faced with 
the consequences of their own history and a growing tide of racial unease hung over the country.

However, it would be wrong to represent the Maori response to their position in the 1970s and 1980s as primarily reactive - this would ignore the more significant efforts to grapple with the consequences of urbanisation and the associated political environment that some Maori were beginning to explore at this time. One of the most prominent and dynamic fruits of this experiment has been the $\mathrm{Te}$ Whanau o Waipareira Trust (the Waipareira Trust). ${ }^{30}$ It serves as a worthy case study at this juncture, because it encapsulates so many of the current issues arising from Maori urbanisation.

Formally incorporated in 1984, the Waipareira Trust is a Maori organisation located in and urban setting: west Auckland. Similarly, and year later, in 1985 the Manukau Urban Maori Authority (MUMA) was established to represent the interests of urban Maori in south Auckland. Both organisations were established by groups of first-generation urban Maori from diverse tribal backgrounds to meet the development needs of their respective communities. Importantly, they are organisations established by Maori for Maori, and lead a number of national debates regarding the status and identity of urban Maori and Maori development.

As a result of the opportunities available to deliver services on behalf of the Government, these organisations have developed a portfolio of business activities that include the delivery of social, health, and training and employment services to the community. The complexity of the business activities of these organisations have become increasingly sophisticated, and in the case of the Waipareira Trust, it is actively engaged in property development and also operates a corporate services division that provides financial, legal, administration and research services for the trust's activities. Following significant legal activity and lobbying in recent years, the trust has received, albeit qualified, Government recognition as a tribe through its exercise of rangatiratanga in its own right. It is now eligible to receive government funding for the delivery of services to its members. ${ }^{31}$ It is also unique in that it serves both Maori and non-Maori members of its 
community which represents some 15,000 households. ${ }^{32}$ The longer-term implications of this service will clearly challenge the traditional identity of communities previously prescribed by their ethnicity alone.

The Waipareira Trust employs approximately 300 staff and is committed to not only providing quality services to its community, but also to providing employment. Central to its core business activities are government contracts. However, recognising that the sustainability of such work is limited, the Trust has embarked on significant property and business investment activity. While the success of many of those ventures has been variable, the determination by the Trust to secure its own rangatiratanga through economic development is to be applauded and encouraged. To that end, perhaps its most significant achievement has been the upholding of the Trust's claim for the recognition of its own rangatiratanga by the Waitangi Tribunal. In its findings the Tribunal usefully opined that

(F)ar from being static, Maori communities have changed over time. No doubt they will continue to do so. They have changed throughout history with hapu growing, disappearing and emerging, their political alliances continuously, and sometimes with major migrations occurring, the migrants regularly gathering adherents from communities far and wide. It is thus apparent that, in 1840 , Maori were not organised into the same communities as they were only 20 years before. There were major and pan-tribal movements in the interim, and the migrations to Wellington in the 1820s and 1930s well show. And those exist today did not all exist in 1840. The concept of iwi authorities has grown, exercising corporate functions previously unheard of, and so too national bodies, each valid if they serve the needs of Maori in a new age. In addition a new urban communities have grown as well, and these for many may now represent the communities of their choice. $^{33}$

On the matter of the Treaty and development, the Tribunal concluded that the Treaty of Waitangi '...did not freeze Maori in time. It accommodates changes for it is the customary 
values and principles that remain the same. The fundamental principle of customary organisation is the survival of the community, requiring that its autonomy is to be protected, and ensuring the location of power and decision-making at the basic level of the functioning community'. 34

Importantly, the Tribunal argued that Maori have been quite capable of adopting institutional arrangements to meet their needs that were not based on kinship, but were Maori none-the-less. This creativity, the Tribunal definitively concluded

...was consistent with a freedom of choice, and there is historical evidence that Maori valued their freedom. We have noted that rangatiratanga arises from the reciprocal relationship between members and leaders of a Maori community. The support and loyalty of the community is a vital ingredient of rangatiratanga, and that flows from the exercise of choice by individuals. Rangatiratanga cannot be imposed on people - the people choose their own rangatira and create their own communities. This aspect of their rangatiratanga, by which Maori control their own group formation and representation, is also guaranteed protection by the Crown in terms of the Treaty. ${ }^{35}$

Having faced considerable opposition, including recognition as a legitimate Maori organisation by traditional Maori groups, the Waipareira Trust and its other urban equivalents continue to be a witness to the resilience of the Maori spirit. Significantly, that spirit is no less than that of their ancestors, whose urbanising activities some millennia previously resulted in the settlement of the Pacific.

The issue of measuring the performance of the urban Maori authorities is complex. Most of the authorities differ in funding arrangements, scale of operations, and range of functions. In addition, several have entered into partnerships with local authorities, and businesses, in addition to the matrix of connections that exist between the authorities and Crown agencies. Moreover, the devices for measurement employed by the various authorities vary, and are usually 
applied for purposes more directly associated with day-to-day operations.

However, notwithstanding these limitations on the availability of statistical data, informal empirical analysis suggests that some broad themes are emerging with respect to the performance of the authorities. One area that can be considered in this context is the expansion of the scope and depth of certain activities. For example, in recent years, the work of Maori authorities has expanded from what was previously seen as the "core; activity of the provision of social services to areas such as property investment, education, health, and political lobbying at local and national levels. The fact that this expansion has been possible is attributable, in part, to the ongoing quality of performance of the majority of urban Maori authorities.

Another indication of success is the fact that various nonaffiliated Maori authorities have applied to join the National Urban Maori Authority, seeing it as a model that suits their individual demands for furthering Maori development. ${ }^{36}$ One of the reasons for this has been the capacity of the National Urban Maori Authority to articulate the demands of its constituents in a manner in which these demands are noticed and responded to.

A further means of assessing the performance of the authorities is through consideration of the extent to which social services in particular - which were formerly the sole domain of Government departments - have been successfully devolved to urban Maori authorities. The quality of these services is monitored by the relevant Government departments as a condition of the tenders for delivery being awarded. This constitutes a major measure of performance.

Building on the successes of the Waipareira Trust and MUMA, the National Urban Maori Authority - the second tier in the Maori response to urbanisation - was formally launched on 3 May 2003. The National Urban Maori Authority has been established with the expectation being that it will formally represent the interests of Maori who not only live outside their tribal boundaries, but also those without any formal tribal allegiance. That this has already been seen to be a challenge to existing organisations such as the New Zealand Maori 
Council is certain. That it will be a successful in its challenge of existing distributional models associated with Treaty of Waitangi settlements that favour generally rural-based iwi is less certain. It mirrors, however, efforts by Maori at the time of the signing of the Declaration of Independence in 1835. Coalition - particularly when there are issues of common interest - is a rational and common feature of Maori politics, and the emergence of the National Urban Maori Authority is a testament to this. In this sense, it confirms that the core principles of adaptation and advancement - that have characterised Maori communities since they were first established in New Zealand - continue to be both a dominant trait and a guiding force in Maori society.

The presence of urban Maori authorities throughout the country is a testament to the fact that they fulfil several needs of the Maori communities that they represent. As the experience of Waipareira reveals, there are aspects of these organisations that, in a few cases, do not mirror the ideal model in a few selected areas, although if the same range of non-Maori organisations were subject to the same intense and protracted scrutiny, similar deficiencies would certainly be observed. This reflects one of the more significant challenges facing the urban Maori authorities: overcoming negative stereotypes - especially in sections of the news media - about the nature of Maori organisations. There is frequently the tacit presumption that Maori are somehow unable to operate organisations to the same levels of performance as non-Maori. Yet, based on the anecdotal feedback from recipients of the services of urban Maori authorities from throughout the country - the opposite could be said to be more true: that it is the non-Maori organisations that fail to deliver to the levels and in the manner that the urban Maori authorities do.

\section{Conclusion}

Urbanisation has undoubtedly redefined the shape and perception of Maori communities, but does this mean that it has in any way undermined these communities? Certainly 
not. In fact, the debate for or against Maori urbanisation and its most visible manifestation - Urban Maori Authorities - is an unhelpful and unnecessary one. It is clear that Maori development aspirations may be enhanced by supporting Maori communities to create, develop and manage their own development needs. Currently the needs of Maori in general continue to outstrip the capacity of Maori to provide their own economic solutions to their socio-economic plight. Accordingly, it is incumbent upon the Government and its successors to ultimately realise the principles articulated in the Treaty of Waitangi. Simplistically they articulate the principles of a partnership between two peoples, the full and equitable participation by Maori in the affairs of their own country, and the enjoyment of the protection by the Government of their rights as New Zealand citizens. ${ }^{37}$ Such principles lie on infertile ground whilst there exists the pragmatic acceptance that the fundamental right of the freedom of association and the consequent identity ascribed to that association are somehow to be denied a large number of those who describe themselves as Maori. Just like any other people, Maori have an inalienable right to determine the makeup of their communities. Maori society cannot be treated - as it unfortunately has by some analysts - as a sort of museum exhibit: locked into a shape that bears little relevance to contemporary society, and which is not allowed to develop in the way that all societies are naturally inclined to do. The politics of ethnicity and the politics of identity have unfortunately found themselves at the centre of a moral and ethical struggle between the ideologies of the left and the right. In the meantime, those caught in the middle are largely Maori who continue to share a common socio-economic plight with a single and determined will to assist themselves. Left to the vagaries of Government policy, Maori may continue to remain over-represented in negative social and economic statistics. Evidence suggests however, that the resilience inherited from their Austronesian forebears may yet conquer the challenges of both colonisation and urbanisation. Certainly a stronger partnership between the Government and Maori their communities, however defined, provides a strong 
position from which to address the challenges facing New Zealand society as a whole.

\section{Notes}

1 W. W. Rostow, The Processes of Growth: A Non-Communist Manifesto, London, 1953; W. W. Rostow, The Stages of Economic Growth, Cambridge, 1961; N. J. Smelser, 'The Modernisation of Social Relations', in W. Myron, (ed.), Modernisation: The Dynamics of Growth, Washington, 1966.

2 A. G. Frank, Sociology of Development and Underdevelopment of Sociology, London, 1971.

3 R. Walker, Ka Whawhai Tonu Matou: Struggle Without End, Auckland, 1990 , p. 55

4 I. C. Campbell, A History of the Pacific Islands, 1989, p. 33; J. Poulsen, Early Tongan Pre-History: The Lapita Period on Tongatapu, Canberra, 1987, pp. 152-3; J. E. Weckler, Polynesian Exploration of the Pacific, Washington, 1943, chap. 1.

5 Op. cit.

6 See for example R. Halbert, Horouta, The History of the Horouta Canoe, Gisborne and East Coast, Reed Books, Auckland, 1999, ISBN 079000623

See 'Report from the Select Committee of the House of Lords on the Present State of the Islands of New Zealand', Great Britain Parliamentary Papers 1837-1840, Vol. 21, London, 1840.

$8 \quad$ Op. cit

9 James Busby was appointed British resident to New Zealand in 1832 and arrived $\mathrm{n}$ the country the following year. R. W. Hay to J. Busby, 28 March 1832 , in CO 202/28.

10 E. Ramsden, Busby of Waitangi: H.M.'s Resident at New Zealand 1833 1840 , Wellington, 1942 , p. 92; He Whakaputanga o te Rangatiratanga o Nu Tireni - A Declaration of Independence for New Zealand, 28 October, 1835, National Archives of New Zealand, Wellington.

11 Op. cit.

12 Normanby to W. Hobson, 14, 15 August 1839, in Great Britain Parliamentary Papers, 1840, Vol. 23, pp. 37-45.

13 P. Moon, Te Ara Ki Te Tiriti: The Path to the Treaty of Waitangi, Auckland, 2002.

14 The total population in 1900 was approximately 820,000. Statistics New Zealand, Population of North and South Islands, 1858-1996 selected censuses.

15 Successive New Zealand Governments maintained the policy of alienating Maori land throughout the nineteenth century.

16 For a nineteenth-century survey of this problem, see H. H. Ngapua, in Parliamentary Debates, Vol. XCIX, 29 October 1897, pp. 327-331.

17 Those policies included the destruction of the Maori language resulting from official Education Department policy that required Maori to be actively discouraged in favour of English in the classroom. While $90 \%$ of Maori schoolchildren had been able to speak Maori in 1913, by 1953 that figure had dropped to $26 \%$ and to less than $5 \%$ in 1975 . Waitangi Tribunal Te Reo Maori Report, (Wai 11) 1986. 
18 Te Puni Kokiri, Ministry of Maori Development, Draft report, "Maori Economic Development - Identifying Causes of Disadvantage and Strategies for Accelerating Maori Economic Development", Wellington, p. 8. 9 See supran 24 at p. 21, as an exception wherein it is argued that it in the interests of civil society and the state to address the historical disadvantages of a minority group that are not only creating costs, but preventing their contributing fully to general wealth. More importantly it is in the self-interest of an economically rational society to be concerned with Maori economic development.

20 See for example Robert Nozick, "Anarchy, State and Utopia” (New York: Basic Books, 1974) who argues that a system based on property rights, where private property can be acquired and transferred only through voluntary exchange is the fairest means by which wealth should be distributed in a community.

21 P. Keiha, The Contribution of Science and Technology to Business, The Academy Council of the Royal Society of New Zealand, Wellington, New Zealand. Published in Leadership Priorities for New Zealand Science and Technology, Royal Society Miscellaneous Series, 1998, ISBN 0-908654-91X, pp. 110-114

22 The Maori asset base has been conservatively estimated to be in excess of $\$ 10$ billion; Maori land - $\$ 1,659$ million, Treaty of Waitangi Fisheries Commission - \$400 million, Self employed businesses - \$2,000 million, Maori Corporate Enterprises and Trust Boards - \$547 million and Maori owned dwellings $\$ 6,000$ million. See "The Nature and Extent of the Maori Economic Base", a report prepared for The Ministry of Maori Development by Dennis Rose, Paul Morgan and Grant Andrews, Business and Economic Research Ltd and Federation of Maori Authorities, Wellington, 1997, p. 39.

23 N. J. Smelser. Also see D. C. McClelland, 'The Achievement Motive in Economic Growth', in G. D. Ness, (ed.), The Sociology of Economic Development: A Reader, New York, 1970.

24 R. M. McIver and C. H. Page, Society: An Introductory Analysis, London, 1961, pp. 8-10

25 L. Wirth, 'The Scope and Problems of the Community', in A. J. Reiss Jr. (ed.), Louis Wirth on Cities and Social Life, Chicago, 1964, pp. 165-175.

26 A fuller theoretical discussion of urbanisation and its relationship with capitalism is provided in A. Giddens, Sociology: A Brief but Critical Introduction, Second Edition, London, 1986, pp. 100-111.

27 A. Giddens, p. 112.

28 New Zealand Now, Maori, 1998 Edition, Statistics New Zealand, Wellington, New Zealand ISBN 0-478-20727-1

$29 \quad$ Supra n6 at 13

30 Literally, 'the family of Waipareira'. Waipareira is the Maori name for West Auckland

31 Te Whanau o Waipareira Report, Wai 414, Waitangi Tribunal Report, Wellington, 1998, ISBN 1-86956-234-8

321996 Census of Population and Dwellings, Statistics New Zealand

33 Te Whanau o Waipareira Report, Wai 414, Waitangi Tribunal Report, Wellington, 1998, ISBN 1-86956-234-8, p. 218

Op. cit.

Op. cit

See NUMA Meeting Minutes, 21 February 2004.

See G. S. Orr, 'Principles Emerging from Waitangi Tribunal Decisions', unpublished paper presented to Tribunal Members, Wellington, 1989; J. Hayward, The Principles of the Treaty of Waitangi. 